\title{
PROGNOZOWANIE INFLACJI W POLSCE PRZY UŻYCIU MODELU STOCKA I WATSONA
}

\begin{abstract}
$\mathrm{Z}$ a ry s tre ś c i. W artykule przeprowadzono badania dotyczące trafności prognoz otrzymanych za pomocą modelu Stocka i Watsona. Rozważono różne postacie tego modelu i zbadano, które z nich dają możliwość uzyskania najtrafniejszej prognozy. Badania empiryczne dotyczyły inflacji w Polsce w latach 1992-2008. Ostatni rok posłużył do oceny jakości prognoz. Badania przeprowadzono na podstawie wskaźnika cen konsumenta CPI. Uzyskane wyniki nie potwierdzają jednoznacznej przewagi modelu Stocka i Watsona, w prognozowaniu inflacji, nad standardowym modelem autoregresyjnym.
\end{abstract}

S ło w a k l u c z o w e: model lokalnego poziomu, prognozowanie, inflacja.

\section{WSTĘP}

Problem prognozowania inflacji, zarówno w literaturze polskiej, jak i zagranicznej, znany jest od dawna. Ciągle jednak nie można wskazać jednoznacznie najlepszej metody jej prognozowania. W najnowszych badaniach, przeprowadzonych przez Stocka i Watsona $(2007,2008)$, proponowany przez nich model będący naturalna modyfikacją, znanego wcześniej w literaturze przedmiotu, modelu lokalnego poziomu, dał najbardziej trafne prognozy kwartalnej inflacji w Stanach Zjednoczonych. W swoim badaniu Stock i Watson porównali trafność ponad kilkudziesięciu modeli, m.in. szeregów czasowych ARIMA, opartych na krzywej Philipsa oraz NAIRU. Przedstawione w bieżącym artykule badania maja po pierwsze sprawdzić, proponowane przez autora, modyfikacje oryginalnego modelu Stocka i Watsona, po drugie, ze względu na charakter danych, ocenić ich przydatność do prognozowania miesięcznej inflacji w Polsce.

Układ artykułu jest następujący. W części drugiej, oprócz podstawowego modelu Stocka i Watsona, omówiono modele wykorzystujące procesy GARCH z warunkowym rozkładem normalnym i t-Studenta. Do prognozowania inflacji, zaproponowano również, model autoregresyjny ze współczynnikami generowa- 
nymi przez proces błądzenia przypadkowego. W części trzeciej porównano trafność prognozy, uzyskanej z proponowanych modeli. W tym celu posłużono się pierwiastkiem względnego błędu średniokwadratowego (ang. Relative Root Mean Squared Error; RRMSE) oraz medianą i odchyleniem międzykwartylowym gęstości predyktywnych. Na końcu artykułu zamieszczono wnioski.

\section{MODEL LOKALNEGO POZIOMU ZE ZMIENNĄ WARIANCJĄ I WARUNKOWYM ROZKŁADEM T-STUDENTA}

Do prognozowania inflacji Stock i Watson (2007) użyli model lokalnego poziomu, który ma postać zbliżoną do następującego modelu:

$$
\begin{aligned}
& y_{t}=\delta_{t}+\varepsilon_{t}, \quad \varepsilon_{t} \sim N\left(0, \sigma_{t}^{2}\right), \\
& \delta_{t}=\delta_{t-1}+\eta_{t}, \quad \eta_{t} \sim N\left(0, \omega_{t}^{2}\right),
\end{aligned}
$$

gdzie przez $y_{t}$ dla $t=1, \ldots, T$ oznaczono obserwacje zmiennej zależnej, $\delta_{t}$ jest bieżącym, nieobserwowalnym bezpośrednio poziomem procesu w czasie $t$, natomiast $\varepsilon_{t}$ jest białym szumem w równaniu obserwacji. Przyjmuje się, że zmiana w czasie poziomu obserwowanego procesu odbywa się według procesu błądzenia przypadkowego z błędem $\eta_{t}$. Warunkowe wariancje są opisane poprzez procesy stochastycznej zmienności:

$$
\begin{aligned}
& h_{\text {szum }, t}=\rho_{\text {szum }} h_{\text {szum }, t-1}+\zeta_{\text {szum }, t}, \\
& h_{\text {stan }, t}=\rho_{\text {stan }} h_{\text {stan }, t-1}+\zeta_{\text {stan }, t},
\end{aligned}
$$

gdzie $\varepsilon_{t} \sim N\left(0, \sigma_{t}^{2}\right)$ i $\eta_{t} \sim N\left(0, \omega_{t}^{2}\right), \sigma_{t}^{2}=\exp \left(h_{\text {szum }, t}\right)$ i $\omega_{t}^{2}=\exp \left(h_{\text {stan }, t}\right)$ oraz $\rho_{\text {szum(stan) }} \in(-1,1)$, a także $\zeta_{\text {szum(stan) }} \sim N\left(0, \gamma_{\text {szum(stan })}^{2}\right)$. Model ten, w odróżnieniu od modelu Stocka i Watsona (2007), jest postacią bardziej ogólną, ponieważ współczynnik autoregresji może przyjmować wartości jedynie w obszarze gwarantującym stacjonarność warunkowych wariancji, a także, inaczej niż w oryginalnym modelu posiada dwie oddzielne wariancje resztowe $\mathrm{w}$ równaniach dla $h_{t}$.

Dla $\sigma_{t}^{2}=\sigma^{2}$ i $\omega_{t}^{2}=\omega^{2}$ model (1)-(2), redukuje się do standardowego modelu lokalnego poziomu. Własności tego modelu opisują m.in. Muth, (1960), Harvey (1989), West i Harrison (1989), Durbin i Koopman (2001) oraz Koop (2003).

Kolejne dwa modele to modele lokalnego poziomu, w których wariancja warunkowa w równaniu obserwacji i trendu jest opisana jako $\operatorname{GARCH}(1,1)$. $\mathrm{W}$ tym przypadku rozpatrzono dwa warianty. Pierwszy, to model w którym reszty (w równaniu obserwacji i trendu) przyjmują warunkowe rozkłady normalne (LL-GARCH) oraz drugi, w którym założono grubsze ogony poprzez 
przyjęcie warunkowych rozkładów t-Studenta (LL-GARCH-Student). Własności modelu lokalnego poziomu, w którym warunkowe wariancje w równaniu obserwacji i nieobserwowalnego trendu są procesem $\operatorname{GARCH}(1,1)$, opisują Pellegrini, Ruiz i Espasa $(2007,2008)$.

Model LL-GARCH ma następujące procesy resztowe w równaniu obserwacji i stanu:

$$
\varepsilon_{t} \sim N\left(0, \sigma_{t}^{2}\right) \text { i } \eta_{t} \sim N\left(0, \omega_{t}^{2}\right),
$$

gdzie:

$$
\begin{aligned}
& \sigma_{t}^{2}=h_{\text {szum }, t} \text { i } \omega_{t}^{2}=h_{\text {stan }, t}, \\
& h_{\text {szum }, t}=b_{1, \text { szum }} h_{\text {szum }, t-1}+a_{0, \text { szum }}+a_{1, \text { szum }}\left(E \varepsilon_{t-1}\right)^{2}, \\
& h_{\text {stan }, t}=b_{1, \text { stan }} h_{\text {stan }, t-1}+a_{0, \text { stan }}+a_{1, \text { stan }}\left(E \eta_{t-1}\right)^{2},
\end{aligned}
$$

natomiast odpowiednie reszty w modelu LL-GARCH-Student, oznaczono w następujący sposób:

$$
\varepsilon_{t} \sim t\left(0, \frac{v_{\text {szum }}}{\left(v_{\text {szum }}-2\right) \sigma_{t}^{2}}, v_{\text {szum }}\right) \text { i } \eta_{t} \sim t\left(0, \frac{v_{\text {stan }}}{\left(v_{\text {stan }}-2\right) \omega_{t}^{2}}, v_{\text {stan }}\right),
$$

gdzie $t(a, P, v)$ oznacza jednowymiarowy rozkład Studenta o niecentralności $a$, precyzji $P$ i stopniach swobody $v$. W modelach $\operatorname{GARCH}(1,1)$ nałożono standardowe założenia zapewniające dodatniość i skończoność warunkowych wariancji (por. Bos, 2001):

$$
\begin{aligned}
& a_{0, \text { szum (stan) }} \equiv 1-b_{1, \text { szum(stan) }}-a_{1, \text { szum }(\text { stan })}, \\
& b_{1, \text { szum }(\text { stan })} \geq 0, a_{1, \text { szum (stan) }} \geq 0, a_{1, \text { szum (stan) }}+b_{1 \text { szum (stan) }}<1 .
\end{aligned}
$$

Kolejny model, to model autoregresyjny $\mathrm{z}$ parametrami generowanymi przez procesy błądzenia przypadkowego, wraz z warunkową wariacją $\mathrm{w}$ równaniu obserwacji typu SV. Ma on następującą postać:

$$
\begin{aligned}
& y_{t}=\delta_{0 t}+\delta_{1 t} y_{t-1}+\delta_{2 t} y_{t-2}+\varepsilon_{t}, \varepsilon_{t} \sim N\left(0, \sigma_{t}^{2}\right), \\
& \delta_{i t}=\delta_{i, t-1}+\eta_{i t}, \quad \eta_{i t} \sim N\left(0, \omega_{i}^{2}\right) \text { dla } i=0,1,2,
\end{aligned}
$$

gdzie:

$$
\varepsilon_{t} \sim N\left(0, \sigma_{t}^{2}\right), \quad \sigma_{t}^{2}=\exp \left(h_{\text {szum }, t}\right) \quad \text { oraz } \quad h_{\text {szum }, t}=\rho_{\text {szum }} h_{\text {szum }, t-1}+\zeta_{\text {szum }, t},
$$
$\rho_{\text {szum }} \in(-1,1)$, a także $\zeta_{\text {szum }} \sim N\left(0, \gamma_{\text {szum }}^{2}\right)$.

Model ten wyraża się symbolem RCA(2)-SV (RW). Podobny model omawiają Koop i Potter (2001) dla inflacji w Stanach Zjednoczonych. 
Nakładając warunki ograniczające na wariancje $\omega_{i}^{2}=0$ dla $i=0,1,2$, w modelu (10) - (11), uzyskuje się ostatni model, czyli standardowy model $\mathrm{AR}(2)-\mathrm{SV}$ :

$$
y_{t}=\delta_{\text {const }}+\delta_{1, \text { const }} y_{t-1}+\delta_{2, \text { const }} y_{t-2}+\varepsilon_{t}, \varepsilon_{t} \sim N\left(0, \sigma_{t}^{2}\right),
$$

Wyniki estymacji i porównanie mocy objaśniającej rozważanych modeli, dla analizowanego szeregu, zawiera artykuł Kwiatkowskiego (2009).

\section{PROGNOZOWANIE INFLACJI}

W tej części artykułu sprawdzono, czy proponowane modele skutecznie prognozują wartość wskaźnika inflacji CPI. W tym celu dokonano prognozy inflacji oraz oceniono jej trafność $\mathrm{w}$ następstwie stosowania różnych modeli. Łączna liczba obserwacji wskaźnika cen konsumenta, użyta w badaniu, wyniosła $T+T^{\prime}+1=204$ miesiące. Przed przystapieniem do analizy badany szereg oczyszczono z sezonowości za pomocą średniej ruchomej scentrowanej. Logarytmy obserwacji w okresie od stycznia 1992 do grudnia 2007 roku posłużyły jako podstawowy zbiór danych $(t=1, \ldots, T=192)$. Następnie w miesiącach od stycznia do sierpnia 2008 roku, obliczono prognozy na jeden okres wprzód $\left(T^{\prime}+1=12\right)$, dokonując za każdym razem aktualizacji zbioru obserwacji, $y^{(t)}$, $t=T, \ldots, T+T^{\prime}$. Wybrana procedura jest stosunkowo żmudna, ponieważ wymaga, przy każdej aktualizacji, ponownej estymacji parametrów i uzyskania realizacji z brzegowych rozkładów predyktywnych. Dodatkowo, całą procedurę należy przeprowadzić pięciokrotnie, co daje łącznie 60 estymowanych modeli bayesowskich.

Podstawą analizy są jednomiesięczne rozkłady predyktywne w miesiącu $t$, warunkowe względem omówionych powyżej modeli: $M_{1}, \ldots, M_{5}$. Uzyskano je za pomocą metod Monte Carlo (por. Pipień, 2006):

$$
p\left(y_{t+1} \mid y^{(t)}, M_{i}\right) \text {, dla } i=1, \ldots, 5 ; t=T, \ldots, T+T^{\prime} .
$$

Analizę trafności prognoz obliczono na podstawie różnicy między kwartylami tzw. odległości międzykwartylowej rozkładu predyktywnego. Jest to miara rozproszenia, co oznacza, że może być wykorzystana jako miara niepewności ex ante oraz służyć do oceny trafności ex post prognozy (Osiewalski, 2001). Dodatkowo, ocenę trafność prognoz dokonano na podstawie charakterystyk rozkładu pierwiastka względnego błędu średniokwadratowego RRMSE, który jest nieliniową funkcją zmiennych predyktywnych $\mathrm{i} w$ tym przypadku dany jest wzorem:

$$
\operatorname{RRMSE}_{t+1, i} \mid y^{(t+1)}, M_{i}, M_{5}=\sqrt{\frac{\left(y_{t+1} \mid y^{(t)}, M_{i}-y_{t+1}\right)^{2}}{\left(y_{t+1} \mid y^{(t)}, M_{5}-y_{t+1}\right)^{2}}} .
$$


Ponieważ nie ma pewności, czy tak zadana zmienna losowa ma skończone momenty w ocenie trafności prognoz, można posłużyć się medianą rozkładu RRMSE oraz krańcami 95\% przedziałów o najwyższej gęstości. Proponowany wzór umożliwia przede wszystkim porównanie względnej trafności prognoz konkurujących modeli, w stosunku do jedynego modelu z nielosowymi parametrami w średniej, tj. AR(2)-SV. Mediana a posteriori równa jeden, wskazuje na identyczną trafność (oczywiście według tego kryterium), jak w przypadku zwykłego modelu AR(2)-SV. Z kolei mediana poniżej jedynki, informuje, że bardziej trafna jest prognoza obliczona za pomocą modelu umieszczonego w liczniku, natomiast mediana powyżej jedynki mówi, że dokładniejszą prognozę uzyskano przy użyciu podstawowego modelu autoregresyjnego. Tabela 1 przedstawia poszczególne charakterystyki rozkładu współczynnika RRMSE oraz wartości prawdopodobieństwa dla których przyjmuje on wartości mniejsze niż jeden, tj. $\operatorname{Pr}\left(R R M S E_{t+1, i} \mid y^{(t)}, M_{i}, M_{5}<1\right)$. Informacja ta jest zamieszczona w trzeciej linii tabeli 1, w nawiasach półokragłych. Pogrubioną czcionką zaznaczono przypadki dla których rozkład współczynnika RRMSE ma medianę poniżej jedynki.

Wydaje się, że najbardziej trafne prognozy uzyskano dla podstawowego modelu autoregresyjnego, czyli AR(2)-SV. Model LL-SV, w pięciu przypadkach na dwanaście, dał dokładniejsze prognozy niż zwykły model AR(2)-SV. W lutym oraz od maja do sierpnia, mediany rozkładu współczynnika RRMSE, miały wartości wyraźnie poniżej jedynki. Prognozy inflacji, uzyskane za pomocą modelu RCA(2)-SV (RW), prowadziły do redukcji błędów jedynie w dwóch przypadkach na dwanaście, natomiast prognozy otrzymane za pomocą modelu LL-GARCH-Student, były zbliżone do prognoz uzyskanych w modelu LL-SV. Rozkłady a posteriori współczynnika RRMSE charakteryzują się dużym rozproszeniem. Można zatem sądzić, że wszystkie modele charakteryzują się podobną trafnością, chociaż bywały przypadki, w których modele LL-SV i LLGARCH-Student uzyskały wyraźną przewagę nad pozostałymi. Teza ta znajduje potwierdzenie $\mathrm{w}$ wartościach ilorazu prawdopodobieństw a posteriori hipotez $R R M S E<1$ i $R R M S E>1$. We większości przypadków, wartości ilorazu były bardzo zbliżone do jedynki, zdarzały się jednak przypadki, w których iloraz ten wyniósł 2,17 , czyli był ponad dwukrotnie większy niż zakładany iloraz prawdopodobieństwa a priori, równy jeden. W analizowanych przypadkach, położenie mediany wobec dolnego i górnego krańca przedziału o najwyższej gęstości wskazuje, że współczynnik RRMSE ma silną asymetrią prawostronną, co oznacza, że gdyby jako ocenę trafności prognoz użyto dominanty to, tego typu charakterystyka byłaby korzystna dla modeli Stocka i Watsona, zwłaszcza, że $\mathrm{w}$ wielu przypadkach np. w styczniu, marcu i kwietniu, mediana a posteriori jest bardzo blisko jedynki. 
Tabela 1. Ocena jakości prognoz wskaźnika cen konsumenta CPI, otrzymanych za pomocą modeli LL-GARCH, LL-GARCH-Student, LL-SV i RCA(2)-SV (RW), względem AR(2)-SV

\begin{tabular}{|c|c|c|c|c|}
\hline Data & LL-GARCH & $\begin{array}{c}\text { LL-GARCH- } \\
\text { Student }\end{array}$ & LL-SV & $\begin{array}{c}\mathrm{RCA}(2)-\mathrm{SV} \\
\text { (RW) }\end{array}$ \\
\hline $\begin{array}{l}\text { Symbol } \\
\text { modelu }\end{array}$ & $M_{1}$ & $M_{2}$ & $M_{3}$ & $M_{4}$ \\
\hline 2008M01 & $\begin{array}{c}1,2321 \\
{[0,0024 ; 13,4793]} \\
(0,4329)\end{array}$ & $\begin{array}{c}1,1879 \\
{[0,0024 ; 14,3584]} \\
(0,4437)\end{array}$ & $\begin{array}{c}1,0603 \\
{[0,0027 ; 12,4415]} \\
(0,4813)\end{array}$ & $\begin{array}{c}1,2132 \\
{[0,0012 ; 13,9897]} \\
(0,4340)\end{array}$ \\
\hline 2008M02 & $\begin{array}{c}1,2806 \\
{[0,0015 ; 15,9193]} \\
(0,4209)\end{array}$ & $\begin{array}{c}1,0777 \\
{[0,0020 ; 14,7671]} \\
(0,4768)\end{array}$ & $\begin{array}{c}\mathbf{0 , 9 6 4 1} \\
{[0,0011 ; 12,2829]} \\
(0,5110)\end{array}$ & $\begin{array}{c}1,1284 \\
{[0,0010 ; 14,3489]} \\
(0,4616)\end{array}$ \\
\hline 2008M03 & $\begin{array}{c}1,2805 \\
{[0,0017 ; 17,3806]} \\
(0,4252)\end{array}$ & $\begin{array}{c}1,1114 \\
{[0,0022 ; 16,9929]} \\
(0,4700)\end{array}$ & $\begin{array}{c}1,0789 \\
{[0,0012 ; 14,9601]} \\
(0,4781)\end{array}$ & $\begin{array}{c}1,1860 \\
{[0,0011 ; 15,4595]} \\
(0,4463)\end{array}$ \\
\hline 2008M04 & $\begin{array}{c}1,4329 \\
{[0,0020 ; 18,4806]} \\
(0,3877)\end{array}$ & $\begin{array}{c}1,2296 \\
{[0,0014 ; 17,5506]} \\
(0,4383)\end{array}$ & $\begin{array}{c}1,0113 \\
{[0,0015 ; 14,3477]} \\
(0,4976)\end{array}$ & $\begin{array}{c}1,1665 \\
{[0,0024 ; 16,0866]} \\
(0,4544)\end{array}$ \\
\hline 2008M05 & $\begin{array}{c}1,0077 \\
{[0,0023 ; 6,6457]} \\
(0,4963)\end{array}$ & $\begin{array}{c}\mathbf{0 , 9 5 7 2} \\
{[0,0021 ; 6,1487]} \\
(0,5197)\end{array}$ & $\begin{array}{c}\mathbf{0 , 9 7 7 9} \\
{[0,0032 ; 5,9596]} \\
(0,5115)\end{array}$ & $\begin{array}{c}\mathbf{0 , 9 7 4 4} \\
{[0,0028 ; 6,2553]} \\
(0,5118)\end{array}$ \\
\hline 2008M06 & $\begin{array}{c}1,0865 \\
{[0,0018 ; 14,0669]} \\
(0,4746)\end{array}$ & $\begin{array}{c}\mathbf{0 , 9 6 8 6} \\
{[0,0012 ; 14,1857]} \\
(0,5096)\end{array}$ & $\begin{array}{c}\mathbf{0 , 9 2 4 5} \\
{[0,0018 ; 12,5300]} \\
(0,5237)\end{array}$ & $\begin{array}{c}1,2227 \\
{[0,0015 ; 14,6059]} \\
(0,4347)\end{array}$ \\
\hline 2008M07 & $\begin{array}{c}\mathbf{0 , 8 1 3 5} \\
{[0,0019 ; 7,2154]} \\
(0,5782)\end{array}$ & $\begin{array}{c}\mathbf{0 , 8 4 2 5} \\
{[0,0020 ; 7,8001]} \\
(0,5697)\end{array}$ & $\begin{array}{c}\mathbf{0 , 9 4 9 2} \\
{[0,0033 ; 8,1448]} \\
(0,5228)\end{array}$ & $\begin{array}{c}\mathbf{0 , 9 5 5 0} \\
{[0,0017 ; 8,1816]} \\
(0,5175)\end{array}$ \\
\hline 2008M08 & $\begin{array}{c}\mathbf{0 , 8 3 4 8} \\
{[0,0015 ; 5,4231]} \\
(0,5781) \\
\end{array}$ & $\begin{array}{c}\mathbf{0 , 7 3 5 8} \\
{[0,0012 ; 4,9710]} \\
(0,6307) \\
\end{array}$ & $\begin{array}{c}\mathbf{0 , 6 0 9 1} \\
{[0,0006 ; 4,3701]} \\
(0,6855) \\
\end{array}$ & $\begin{array}{c}1,0050 \\
{[0,0037 ; 6,0601]} \\
(0,4975)\end{array}$ \\
\hline 2008M09 & $\begin{array}{c}1,2175 \\
{[0,0033 ; 10,6929]} \\
(0,4202)\end{array}$ & $\begin{array}{c}1,2614 \\
{[0,0038 ; 11,5840]} \\
(0,3961)\end{array}$ & $\begin{array}{c}1,1969 \\
{[0,0048 ; 10,6528]} \\
(0,4209)\end{array}$ & $\begin{array}{c}1,4548 \\
{[0,0054 ; 12,8723]} \\
(0,3448)\end{array}$ \\
\hline $2008 \mathrm{M} 10$ & $\begin{array}{c}1,2169 \\
{[0,0015 ; 16,5847]} \\
(0,4405)\end{array}$ & $\begin{array}{c}1,0384 \\
{[0,0012 ; 15,1860]} \\
(0,4886)\end{array}$ & $\begin{array}{c}1,0543 \\
{[0,0018 ; 15,0973]} \\
(0,4838)\end{array}$ & $\begin{array}{c}1,2572 \\
{[0,0022 ; 17,7720]} \\
(0,4297)\end{array}$ \\
\hline $2008 \mathrm{M} 11$ & $\begin{array}{c}1,1423 \\
{[0,0016 ; 14,9245]} \\
(0,4579)\end{array}$ & $\begin{array}{c}\mathbf{0 , 9 3 8 2} \\
{[0,0016 ; 13,7707]} \\
(0,5170)\end{array}$ & $\begin{array}{c}1,0491 \\
{[0,0026 ; 14,4967]} \\
(0,4851)\end{array}$ & $\begin{array}{c}1,2165 \\
{[0,0029 ; 15,9510]} \\
(0,4410)\end{array}$ \\
\hline 2008M12 & $\begin{array}{c}1,3681 \\
{[0,0016 ; 20,5659]} \\
(0,4032)\end{array}$ & $\begin{array}{c}1,3317 \\
{[0,0027 ; 18,6855]} \\
(0,4049)\end{array}$ & $\begin{array}{c}1,4682 \\
{[0,0033 ; 20,2388]} \\
(0,3807) \\
\end{array}$ & $\begin{array}{c}1,1070 \\
{[0,0011 ; 15,6882]} \\
(0,4667)\end{array}$ \\
\hline
\end{tabular}

$\mathrm{W}$ pierwszej linii podano medianę a posteriori rozkładu RRMSE, w nawiasach kwadratowych jego dolną i górną granicę $95 \%$ przedziału o najwyższej gęstości, a w nawiasach półokragłych wartości prawdopodobieństwa, dla których przyjmuje on wartości mniejsze niż jeden. Pogrubioną czcionką zaznaczono przypadki, w których uzyskano bardziej trafną prognozę niż w modelu AR(2)-SV.

Źródło: obliczenia własne. 


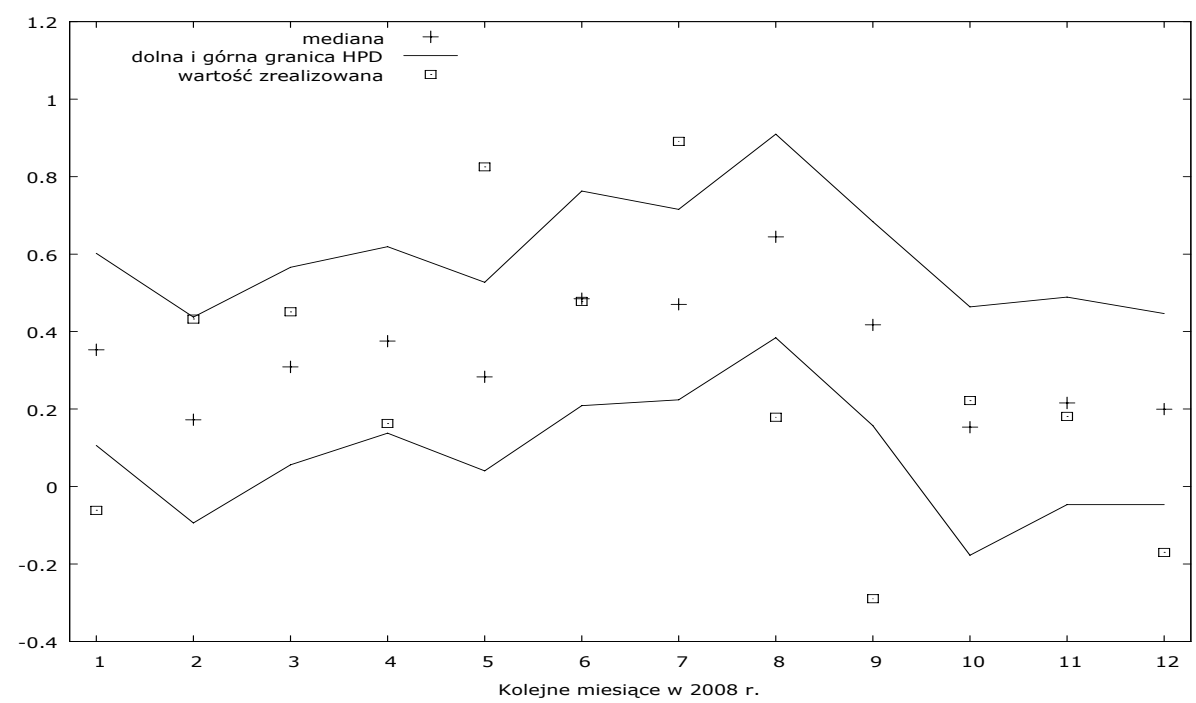

Wykres 1. Wartości zrealizowane oraz mediana gęstości predyktywnych, wraz z dolną i górną granicą przedziału HPD, obliczone za pomocą modelu LL-GARCHStudent

Źródło: obliczenia własne.

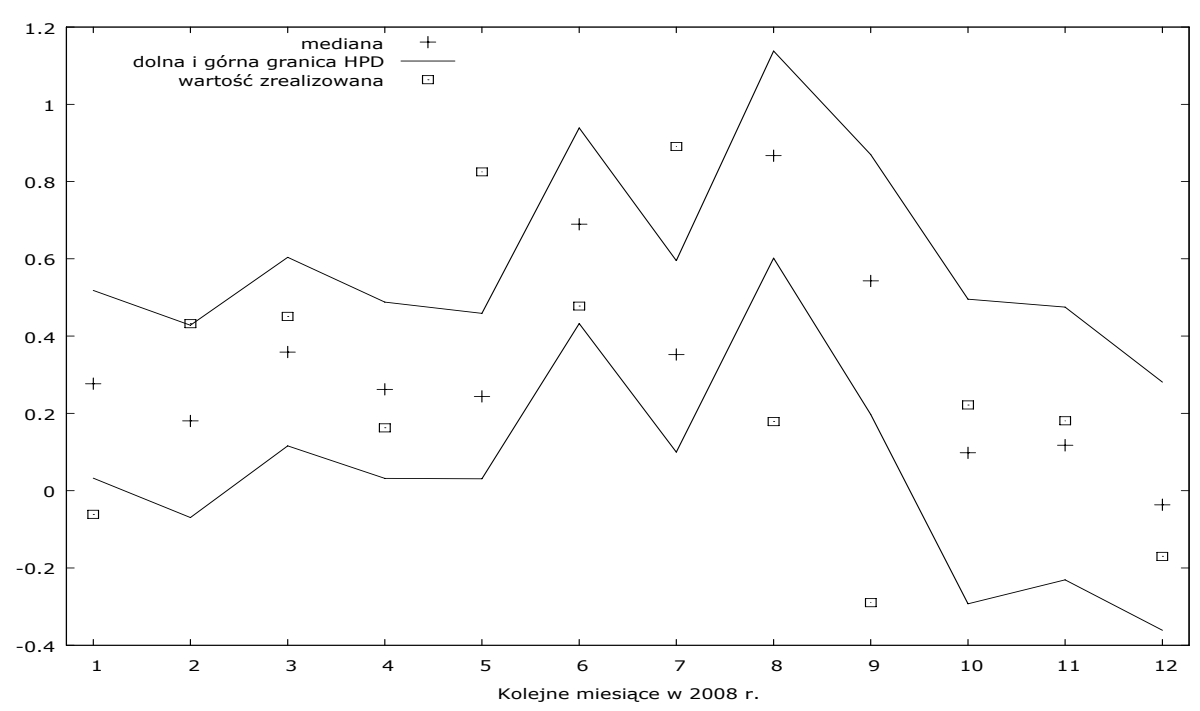

Wykres 2. Wartości zrealizowane oraz mediana gęstości predyktywnych, wraz z dolną i górną granicą przedziału HPD, obliczone za pomocą modelu AR(2)-SV

Źródło: obliczenia własne. 
W tabeli 2, oprócz podanych w nawiasach zrealizowanych wartości zmiennych, zamieszczono mediany oraz kwantyle rzędu 0,25 i 0,75 rozkładów predyktywnych. Jakość prognoz otrzymanych za pomoca przedstawionych tu modeli dla wskaźnika cen konsumenta CPI w Polsce jest bardzo zróżnicowana. Analiza ex post, dla modeli LL-GARCH-Student, LL-SV wykazuje, że zrealizowane poziomy inflacji tylko $\mathrm{w}$ połowie przypadków znajdują się $\mathrm{w}$ obszarze najwyższej gęstości predyktywnej, natomiast w modelu AR(2)-SV, taka sytuacja miała miejsce tylko $\mathrm{w}$ pięciu przypadkach na dwanaście. W sytuacji gdy punktowa prognoza na poziomie mediany okazuje się trafna, zrealizowane wartości leżą najczęściej pomiędzy medianą i kwantylem rzędu 0,75.

Tabela 2. Kwantyle rozkładów predyktywnych obliczone przy użyciu wybranych modeli oraz zrealizowane wartości inflacji

\begin{tabular}{|c|c|c|c|}
\hline Data & LL-GARCH-Student & LL-SV & AR(2)-SV \\
\hline $2008 \mathrm{M} 01$ & 0,3530 & 0,3144 & 0,2769 \\
$(-0,0613)$ & 0,$1060 ; 0,6018$ & 0,$0938 ; 0,5308$ & 0,$0322 ; 0,5183$ \\
\hline $2008 \mathrm{M} 02$ & 0,1723 & 0,2106 & 0,1806 \\
$(0,4324)$ & $-0,0940 ; 0,4375$ & $-0,0251 ; 0,4490$ & $-0,0694 ; 0,4281$ \\
\hline $2008 \mathrm{M} 03$ & 0,3088 & 0,2738 & 0,3587 \\
$(0,4510)$ & 0,$0559 ; 0,5657$ & 0,$0401 ; 0,4976$ & 0,$1161 ; 0,6041$ \\
\hline $2008 \mathrm{M} 04$ & 0,3754 & 0,3039 & 0,2623 \\
$(0,1627)$ & 0,$1376 ; 0,6190$ & 0,$0883 ; 0,5228$ & 0,$0316 ; 0,4881$ \\
\hline $2008 \mathrm{M} 05$ & 0,2833 & 0,2646 & 0,2438 \\
$(0,8252)$ & 0,$0402 ; 0,5270$ & 0,$0636 ; 0,4635$ & 0,$0309 ; 0,4589$ \\
\hline $2008 \mathrm{M} 06$ & 0,4849 & 0,3924 & 0,6895 \\
$(0,4778)$ & 0,$2089 ; 0,7628$ & 0,$1332 ; 0,6608$ & 0,$4326 ; 0,9388$ \\
\hline $2008 \mathrm{M} 07$ & 0,4703 & 0,3831 & 0,3524 \\
$(0,8909)$ & 0,$2237 ; 0,7153$ & 0,$1392 ; 0,6266$ & 0,$1000 ; 0,5953$ \\
\hline $2008 \mathrm{M} 08$ & 0,6447 & 0,5262 & 0,8670 \\
$(0,1788)$ & 0,$3842 ; 0,9097$ & 0,$2287 ; 0,8180$ & 0,$6021 ; 1,1381$ \\
\hline $2008 \mathrm{M} 09$ & 0,4173 & 0,3875 & 0,5429 \\
$(-0,2897)$ & 0,$1570 ; 0,6839$ & 0,$1103 ; 0,6502$ & 0,$1974 ; 0,8700$ \\
\hline $2008 \mathrm{M} 10$ & 0,1533 & 0,2307 & 0,0979 \\
$(0,2219)$ & $-0,1773 ; 0,4639$ & $-0,0925 ; 0,5633$ & $-0,2927 ; 0,4958$ \\
\hline $2008 \mathrm{M} 11$ & 0,2157 & 0,2630 & 0,1176 \\
$(0,1809)$ & $-0,0466 ; 0,4888$ & $-0,0241 ; 0,5553$ & $-0,2308 ; 0,4751$ \\
\hline $2008 \mathrm{M} 12$ & 0,1997 & 0,2529 & $-0,0366$ \\
$(-0,1700)$ & $-0,0468 ; 0,4464$ & $-0,0095 ; 0,5252$ & $-0,3615 ; 0,2809$ \\
\hline
\end{tabular}

$\mathrm{W}$ pierwszej linii zamieszczono medianę, natomiast w drugiej, kwantyle rzędu 0,25 i 0,75 rozkładów predyktywnych. W nawiasach półokragłych zamieszczono zrealizowane wartości inflacji.

Źródło: obliczenia własne.

W pozostałych przypadkach punktowa prognoza poziomu inflacji okazała się zarówno przeszacowana, jak i niedoszacowana. Dotyczy to zarówno modeli z losowymi, jak i nielosowymi parametrami. Na wykresach 1 i 2 zamieszczono wartości zrealizowane oraz mediany gęstości predyktywnych, wraz z dolną i górną granicą przedziału HPD, obliczone przy użyciu modeli LL-GARCHStudent i AR(2)-SV. 


\section{PODSUMOWANIE}

Głównym celem tego artykułu było zastosowanie modeli z parametrami losowo zmiennymi w czasie do prognozowania inflacji w Polsce. Podstawowy szereg obejmował okres od stycznia 1992 do grudnia 2007 roku. Dane pochodzące $\mathrm{z}$ roku 2008 posłużyły z kolei do oceny trafności uzyskanych prognoz. Badania dotyczyły miesięcznych obserwacji wskaźnika cen konsumenta CPI. Prognozy uzyskane za pomocą modeli lokalnego poziomu, czyli LL-GARCHStudent oraz LL-SV, nie uzyskały znaczącej przewagi nad standardowym modelem autoregresyjnym. Oznacza to, że w przypadku danych polskich, używanie tych modeli do prognozowania inflacji nie musi prowadzić do bardziej trafnej prognozy niż tradycyjne modele autoregresyjne. Wydaje się, że można wskazać co najmniej dwie przyczyny tego faktu. Po pierwsze, z własności modelu lokalnego poziomu wiadomo (por. West i Harrison, 1989), że jego pierwsze przyrosty mają taką samą wewnętrzną strukturę jak proces IMA(1,1). Oznacza to, że występuje jedynie ujemna autokorelacja rzędu pierwszego i brak autokorelacji wyższych rzędów. Przeprowadzone badania, zamieszczone w artykule Kwiatkowskiego (2009) wskazują że wskaźnik CPI w Polsce, ma bardziej złożoną strukturę niż wynikałoby to $\mathrm{z}$ założonej hipotezy modelowej, ponieważ oprócz ujemnej autokorelacji rzędu pierwszego, występuje również istotna autokorelacja rzędu drugiego. Stąd właśnie propozycja, aby prognozować inflację przy użyciu modelu AR(2). Po drugie, w proponowanych modelach lokalnego poziomu, dokonano pewnego uproszenia, które polega na tym, że założono wariancje resztowe równe jeden. Problem ten wynika, w dużej mierze, $\mathrm{z}$ trudności numerycznych związanych z uzyskaniem wiarygodnych ocen bezwarunkowych wariancji przy tak małej liczbie obserwacji, co może się przyczyniać do pogorszenia jakości prognoz.

\section{LITERATURA}

Bos C. (2001), Time Varying Parameter Models for Inflation and Exchange Rates, WebDOC, http://citeseer.ist.psu.edu/479611.html (2.04.2008).

Durbin J., Koopman S.J. (2001), Time Series Analysis by State Space Methods, Oxford University Press, Oxford.

Harvey A.C. (1989), Forecasting, Structural Time Series Models and the Kalman Filter, Cambridge University Press, Cambridge.

Koop G. (2003), Bayesian Econometrics, John Wiley \& Sons.

Koop G., Potter S. (2001), Are apparent findings of nonlinearity due to structural instability in economic time series? „The Econometrics Journal”, 4, 1, 37-55.

Kwiatkowski J. (2009), Model Stocka i Watsona oraz jego modyfikacje - analiza inflacji w Polsce, „Folia Oeconomica Cracoviensia”, w druku.

Muth J.F. (1960), Optimal properties of exponentially weighted forecasts, „Journal of the American Statistical Association", 55, 299-306.

Osiewalski J. (2001), Ekonometria bayesowska w zastosowaniach, Wydawnictwo Akademii Ekonomicznej w Krakowie, Kraków.

Pellegrini, S., Ruiz E., Espasa A. (2007), The relationship between ARIMA-GARCH and unobserved component models with GARCH disturbances, wersja niepublikowana. 
Pellegrini S., Ruiz E., Espasa A. (2008), ARIMA-GARCH and unobserved component models with GARCH disturbances: Are their prediction intervals different?, wersja niepublikowana.

Pipień M. (2006), Wnioskowanie bayesowskie w ekonometrii finansowej, Wydawnictwo Akademii Ekonomicznej w Krakowie, Kraków.

Stock J.H., Watson M.W. (2007), Why has U.S. inflation become harder to forecast? „Journal of Money, Credit, and Banking", 39, 3-33.

Stock J.H., Watson M.W. (2008), Phillips curve inflation forecasts, wersja niepublikowana.

West M., Harrison J. (1989), Bayesian Forecasting and Dynamic Models, Springer.

\title{
STOCK AND WATSON MODEL FOR FORECASTING POLISH INFLATION
}

\begin{abstract}
A b s t r a c t. The paper presents various types of local level model, which are based on Stock and Watson's model, recently proposed for U.S. inflation. The main purpose is to use many different local level model specifications, especially with Normal GARCH and Student-t GARCH disturbances, to predict Polish inflation. The paper is a full Bayesian analysis and concerns Consumer Price Index (CPI) in Poland during 1992-2008. The presented results indicate, that standard $\mathrm{AR}(2)-\mathrm{SV}$ is quite suitable for the prediction of Polish inflation.
\end{abstract}

K e y w o r d s: local level model, inflation, conditional heteroscedasticity, Bayesian prediction 